THE RATE OF RETURN TO CORPORATE CAPITAL AND FACTOR SHARES: NEW ESTIMATES USING REVISED NATIONAL INCOME ACCOUNTS AND CAPITAL STOCK DATA

James M. Poterba

Working Paper 6263 
NBER WORKING PAPER SERIES

\title{
THE RATE OF RETURN TO CORPORATE \\ CAPITAL AND FACTOR SHARES: NEW \\ ESTIMATES USING REVISED NATIONAL \\ INCOME ACCOUNTS AND CAPITAL \\ STOCK DATA
}

James M. Poterba

\author{
Working Paper 6263 \\ http://www.nber.org/papers/w6263 \\ NATIONAL BUREAU OF ECONOMIC RESEARCH \\ 1050 Massachusetts Avenue \\ Cambridge, MA 02138 \\ November 1997
}

This paper was presented at the Carnegie-Rochester Conference on Public Policy, April 1997. I am grateful to Rochelle Antoniewicz, Robert Arnold, Robert Barro, Robert Chirinko, Peter Diamond, Robert Mellman, Walter Oi, seminar participants at the Federal Reserve Bank of New York, and especially to Olivier Blanchard, William Nordhaus, and Julio Rotemberg for helpful suggestions. John Simon provided assistance with the OECD Business Sector database. I am grateful to the National Science Foundation for research support through a grant to the National Bureau of Economic Research. A data appendix for this project will be available from the ICPSR in Ann Arbor, MI. This paper is part of NBER's research programs in Corporate Finance and Public Economics. Any opinions expressed are those of the author and not those of the National Bureau of Economic Research.

(C) 1997 by James M. Poterba. All rights reserved. Short sections of text, not to exceed two paragraphs, may be quoted without explicit permission provided that full credit, including $\odot$ notice, is given to the source. 
The Rate of Return to Corporate Capital and Factor

Shares: New Estimates Using Revised National Income

Accounts and Capital Stock Data

James M. Poterba

NBER Working Paper No. 6263

November 1997

JEL Nos. D24, D33, G31

\begin{abstract}
This paper presents new evidence on the rate of return on tangible assets in the United States, incorporating the recently-revised national accounts as well as new estimates of the replacement cost of the reproducible physical capital stock. The pretax return on capital in the nonfinancial corporate sector has averaged 8.5 percent over the $1959-1996$ period. The paper also presents new estimates of the total tax burden on nonfinancial corporate capital, which averages 54.1 percent over this time period. For the 1990 s, this tax rate, which includes corporate income taxes, corporate property taxes, and taxes on stock- and bondholders, averages 42.1 percent of pretax profits. The average pretax rate of return for the $1990-1996$ period is 8.6 percent, and the average after-tax return is 5.0 percent. Although the accounting return to corporate capital has been higher in the mid-1990s than at any previous point in the last two decades, the substantial volatility in the return series makes it premature to conclude that these years represent a departure from past experience.
\end{abstract}

James M. Poterba

Department of Economics, E52-350

Massachusetts Institute of Technology

50 Memorial Drive

Cambridge, MA 02142-1347

and NBER

poterba@mit.edu 
The rate of return to capital is a central parameter in evaluating a range of economic policies that may affect capital formation. The welfare cost of policies that discourage capital accumulation depends on whether the prevailing rate of return is above or below the effective rate of labor force growth, the "golden rule" level derived by Phelps (1961) and Diamond (1965). Although policy discussions, particularly in the area of tax policy, frequently involve debate over policies that might affect the rate of capital accumulation, Summers (1990) notes that there is substantial conceptual and empirical disagreement about the return to expanding the physical capital stock.

One method of estimating the return to capital accumulation uses national income accounts data to calculate the average accounting rate of return on tangible assets. These estimates of the rate of return are not without their limitations, notably the potential divergence between marginal and average returns, but they are widely used. Feldstein (1977) invokes such a return measure in his analysis of the welfare gain from higher national saving. Abel, Mankiw, Summers, and Zeckhauser (1989) develop a generalization of the golden rule that focuses on such a return divided by the capital-output ratio. Feldstein (1996) relies on similar return measures to estimate the welfare gains from the capital accumulation that would flow from a fully-funded Social Security system in the United States.

Recent data releases from the Bureau of Economic Analysis (BEA) provide a warrant for developing new estimates of the rate of return on tangible assets. One of the central features of the revision of the United States' National Income and Product Accounts (NIPA) that was completed in January 1997 was updating the algorithm that is used to calculate depreciation on physical assets. This revision, described in detail by Fraumeni (1997) and Katz and Herman (1997), has generated a new set of estimates for the current- and constantdollar stocks of reproducible physical capital over the $1929-1995$ period. The assumed rates of asset decay in the revised national accounts are generally lower than those in the previous 
set of accounts, so the revision has increased the estimated stock of physical assets. Changes in the depreciation assumptions underlying the NIPA have also resulted in revised estimates of corporate profits net of true economic depreciation on tangible assets.

This paper uses the newly-released data on the replacement value of the net capital stock and the revised national income accounts to update previous estimates of the rate of return on tangible assets in the corporate sector. In addition to tracking this return, which is defined as corporate capital income divided by a measure of the current value of the corporate capital stock, the paper also investigates capital's share of national income. The recent rise in this income share, which equals the rate of return times the capital-output ratio, has attracted attention from both researchers and commentators in the popular press. This income share rose two percentage points between the recession year of 1992 and the most recent year with complete data (1996), and it was at a higher level in 1996 than at any time since 1969. Baker and Mishel (1995) cite changing factor shares as evidence that capital rather than labor has the primary beneficiary of the current economic expansion. Other accounts, such Bernstein (1995), suggest that rising international competition and the diffusion of information technology and workplace automation are inducing fundamental and long-term shifts in the relative rewards of capital and labor. This paper explores whether the developments of the 1990s diverge from historical experience with respect to factor shares, and concludes that it is not yet possible to conclude that recent experience is in any sense unusual.

To place rates of return and factor shares in the United States into perspective, this paper also uses data from the OECD Business Sector Databank to explore the trends in rates of return to tangible assets in the G-7 nations. Data for the period 1966-1996 suggest that the recent United States pattern of rising returns is observed in other industrialized nations, 
with the notable exception of Japan. In spite of this recent comovement, however, the correlation between annual accounting returns on tangible assets in the G-7 countries is low.

The paper is divided into six sections. The first defines the rate of return on corporate tangible assets as well as the capital income share in national income. Section two presents new estimates of the rate of return to capital in the nonfinancial corporate (NFC) sector in the United States, both before and after taxes. This section also considers whether the 1990 s represent an unusual period of corporate returns. The third section reports historical data on corporate capital income relative to national income, and disaggregates changes in this income share into changes due to the pretax return on corporate capital and changes due to the size of the corporate capital stock relative to national income. This section also considers the recent evolution of the labor share of national income. Section four considers international evidence on the rate of return to corporate capital, and it compares recent movements in the profit rate in the United States to that in the other G-7 nations. The fifth section explores the relationship between accounting returns in the national income accounts and alternative measures of the return to capital that could be constructed from capital market data. The analysis focuses on the United States, and finds weak, if any, high-frequency association between these measures. A brief concluding section suggests directions for future research directed at understanding the source of fluctuations in NIPA accounting returns.

\section{The Rate of Return and the Capital Share of National Income: Definitions}

In an economy in which corporations produce all output, there are no taxes (so net national product equals national income), and output of the corporate sector ( $\mathrm{Y}$ ) is measured net of depreciation, the accounting identity for corporate cash flow is

$$
p Y=w L+i B+\pi .
$$

In this expression p denotes the nominal price of corporate output, $w$ is the nominal wage, 
$L$ is the quantity of labor input, $B$ denotes the nominal stock of corporate debt, $i$ is the nominal interest rate on corporate debt, and $n$ denotes corporate profits. The rate of return to corporate capital is defined by:

$$
r_{k}=(\pi+i B) / p_{k} K
$$

where $\mathrm{K}$ denotes the constant-dollar stock of tangible assets used in the corporate sector, and $p_{k}$ is the nominal price of capital assets. The denominator in (2) is the replacement value of the capital stock. The rate of return includes profits, which are ultimately returns to equity investors, either in the form of dividends or retained earnings, as well as interest payments to corporate debt holders. This is the return concept that has been used frequently in attempts to gauge the social return to capital.

The rate of return defined in (2) is related to capital's share of national income', which is defined as

$$
s_{k}=(n+i B) / p Y .
$$

The national income share of labor income is defined, in parallel, as

$$
s_{L}=w L / p Y .
$$

Capital's share of national income is related to the return on capital assets by the identity

$$
s_{k}=r_{k}^{*}(K / Y) *\left(p_{k} / p\right)
$$

The capital share can rise as a result of a rise in the rate of return to capital, a rise in the capital-to-output ratio, or a rise in the relative price of capital goods $\left(p_{k} / p\right)$. These three

'The capital income share of national income includes payments to bondholders. In contrast, the share of profits in national income, which is sometimes cited in popular discussions, excludes interest payouts. This ratio, $(\mathrm{pY}-\mathrm{wL}-\mathrm{iB}) / \mathrm{pY}$ from above, can fluctuate for spurious reasons related to movements in nominal interest rates and corporate financial policy. A decline in nominal interest rates or the debt-to-capital ratio would raise the profit share of national income, with no effect on the capital income share. For this reason the analysis below focuses on the corporate capital income share, not the corporate profit share, in national income. 
factors are not independent. An increase in the relative price of capital goods, or an increase in the required return on capital which raises the equilibrium value of $r_{k}$, should lead to a reduction in the capital-to-output ratio as firms substitute from capital to labor in response to higher capital input prices. The identity in (5) can nonetheless provide a useful way of understanding changes over time in the capital income share.

Defining factor shares is straightforward in the stylized economy described above, but in practice there are a number of measurement difficulties. First, the NIPA divides national income into payments to employees, corporate profits ${ }^{2}$, net interest, as well as two other categories that do not appear in the framework above: rental income and proprietors' income. These flows, which accounted for 2.1 percent and 8.4 percent of national income, respectively, in 1996, include both labor and capital income. If an individual is employed by a firm, his earnings will be treated as employee compensation, but if he owns his own business, his compensation will appear as proprietors income. ${ }^{3}$ The definition of capital and labor shares therefore is somewhat arbitrary.

The national income share of rental income displays substantial fluctuation over the 1959-1996 period, while the proprietors' income share displays a downward trend. Proprietor's income represented 12.1 percent of national income in 1960 , but only 7.9 percent by 1980 . Its share of national income has fluctuated between 6.9 and 8.5 percent over the

\footnotetext{
${ }^{2}$ Corporate profits are defined inclusive of the capital consumption adjustment (CCAdj), which corrects for differences between true economic depreciation on a replacement-cost basis and on a historical cost basis, and the inventory valuation adjustment (IVA), which corrects for inflationary over-statement of corporate profits as a result of nominal gains on inventories and work in progress.

${ }^{3} \mathrm{~A}$ similar problem emerges with some components of rental income. If an individual owns a two-family house, and maintains the building, the return to the labor spent on maintenance activities will appear as rental income, while if he is employed by a landlord who pays him to maintain the building, the value of the same services will be included in labor income.
} 
last fifteen years. Rental income was also a higher fraction of national income at the beginning of the sample -- 4.3 percent in 1960 -- than in more recent years. It reached a low of 1.2 percent of national income in the late 1980s, and has subsequently increased to 2.1 percent in 1996.

In addition to the problem of deciding how much of proprietors' and rental income represent labor income, there is a second potential difficulty with the analysis of national income shares. This is the possibility that changes in the economic environment, particularly in the tax system, can alter the incentives for individuals to receive income in one form or another, and thereby distort the mix of labor versus capital income without any underlying changes in the structure of economic activity. Both Gordon (1997) and Slemrod (1996) discuss methods of transferring income between the personal and the corporate income tax bases, and the effect of corporate and personal income tax rates on the magnitudes of such transfers. The Tax Reform Act of 1986, which reduced the top personal income tax rate to a level below the statutory corporate tax rate, may have encouraged a re-classification of income from corporate to individual earnings, and it may therefore have induced a downward downward bias in post-1986 corporate profits relative to their historical values.

A third practical difficulty with the definition of national income shares concerns the measurement of interest payments. Net interest, a component of national income, equalled $\$ 403.3$ billion in 1996 . This flow is much greater than interest payments by corporations, which equalled $\$ 122.7$ billion. The national income net interest variable includes corporate interest payments as well as interest paid by sole proprietorships and partnerships, and payments by the "other private business" sector, which includes mortgage payments by households. Owner-occupied housing is treated as a "business" in the national accounts, and the interest payments associated with this "business" are a component of net interest. 
Because I am considering the corporate capital income share, since this is the component that is an expanded version of corporate profits, I divide net interest payments into the corporate interest flow and a residual category, net non-corporate interest payments.

\section{The Rate of Return on Tangible Assets in the Nonfinancial Corporate Sector}

In 1996, nonfinancial corporations (NFCs) contributed 71.7 percent of the NIPA profit total of $\$ 611$ billion. Federal Reserve Board seignorage contributed $\$ 19.8$ billion (3.2 percent of the total), other financial corporations 12.8 percent of the total ( $\$ 78.2$ billion), and net profits from the rest of the world represented $\$ 74.7$ billion or 12.2 percent. The latter nets income received by U.S. multinational firms from their subsidiaries operating abroad against payments to foreign multinational firms by U.S. firms with foreign parents.

During the last decade, the financial sector has become a greater contributor to profits. In the last five years of the 1980s, financial corporate profits averaged 5.3 percent of total profits, compared with an average of 11.9 percent of the total in the most recent five years. The "rest of the world" entry has fallen as a share of profits during the 1990s. This reflects the particular definition of foreign profits in the NIPA. For U.S.-based corporations, foreign earnings as a share of total earnings have increased during this period (see Dhawan (1997)). In spite of the growing importance of financial firms, the difficulties in measuring the rate of return to tangible assets deployed in the financial sector has led most previous studies of corporate returns, including Nordhaus (1974), Feldstein and Summers (1977), Holland and Myers (1979), Feldstein, Poterba, and Dicks-Mireaux (1983), and Rippe and Lavin (1995), to focus on returns to nonfinancial corporations. The present study follows in this tradition.

The "standard" rate of return measure for the nonfinancial corporate sector, used in most of the previous studies, equals pretax NFC profits plus net interest payments by NFCs, divided by the replacement cost of NFC tangible assets. This measure understates the return 
to NFC assets, however, because the NIPA remove property taxes, which are classified as an indirect tax, from corporate earnings before defining profits. Feldstein, Poterba, and DicksMireaux (1983) explain that unless property taxes represent fees for services that are provided by state and local governments and that the firm would have needed to purchase otherwise, the pretax return on should include these taxes. NFC property taxes are estimated by multiplying the share of tangible assets held by the nonfinancial corporate sector by state and local property tax receipts. This procedure implicitly assumes that the effective property tax rate on property held by the NFCs is equal to that on property held by all other sectors.

Incorporating the foregoing modification for corporate property tax payments, the pretax rate of return on NFC assets equals:

$$
\begin{aligned}
r_{\mathrm{K}, \mathrm{NFC}}=\text { (Profits Before Tax with IVA \& CCAdj + Net Interest Payments } \\
+ \text { Property Taxes) } / \text { Tangible Assets. }
\end{aligned}
$$

Tangible assets include reproducible tangible assets, plant and equipment, as well as inventories and land. Data on NFC tangible assets are reported in the Federal Reserve Board's Balance Sheets of the U.S. Economy. The data used in the tabulations below are from the September 15, 1997, release of Table B.102 for the nonfarm nonfinancial corporate sector. Since the latest release of the Balance Sheet tables for the entire corporate sector do not yet incorporate the newly-revised BEA capital stocks, I have constructed my own estimates, based on the Balance Sheet data, of the tangible assets for the total corporate sector. ${ }^{4}$ The

\footnotetext{
${ }^{4} \mathrm{Katz}$ and Herman (1997) present new estimates of the aggregate stock of reproducible assets at replacement cost, but they do not present disaggregate estimates for the nonfinancial corporate sector. I have therefore used the ratio of the newly-revised BEA capital stock series from Katz and Herman (1997), to the older unrevised aggregate capital stocks that were the basis for the Balance Sheets data, to adjust the sectoral capital stocks reported in the Balance Sheets. The end-of-1995 value for tangible assets for the total corporate sector is extrapolated from the 1994 value, which is the last value reported in the available Balance Sheets.
} 
Federal Reserve Board reports tangible assets on a year-end basis, so the tangible asset value for year $t$ is the modified Balance Sheet value for year $t-1$.

The recent data revisions substantially affect the estimates of tangible assets. The ratio of the revised to the unrevised nonresidential capital stock for nonresidential capital is greater than 1.4 in the 1950 s, and it declines to a value slightly greater than 1.2 in the 1980 s and $1990 \mathrm{~s}$. For residential capital, the ratio declines from 1.3 in the 1950 s to between 1.2 and 1.25 in the 1980 s and 1990 s. Because the revised capital stocks are substantially larger than the unrevised stocks, rates of return calculated on the basis of these revised stocks will generally be lower than returns based on the unrevised capital stocks. In 1994, the unrevised stock of nonresidential and residential capital accounted for 79.2 percent of the tangible assets held by nonfinancial corporations; land and inventories account for the remainder. The upward revision of the capital stock values, holding constant profits and interest payouts, would therefore lower rates of return by roughly fifteen percent. This effect is partly offset by the downward revision of depreciation flows, which raise corporate profits net of capital consumption.

\section{Rates of Return}

The first column of Table 1 shows the NFC rate of return series including property tax payments, and the second column shows the series excluding these payments. The property tax adjustment raises the average return on corporate capital over the 1959-1996 period by a full percentage point. The property tax declined in importance in the 1980 s, and the difference between the two return series correspondingly narrowed. Since 1990, however, property taxes have increased, and the disparity between the two return series has also widened.

The sample average pretax return for the $1959-1996$ period is 8.5 percent, with a 
time-series standard deviation of 1.0 percent. This is the rate of return estimate that corresponds to the measure, in previous studies, of the social returns to capital investment. The subsample means presented at the bottom of Table 1 show substantial variation across decades in the pretax return to NFC assets. The return in the 1960 s averaged 10.2 percent, as indicated by the property-tax inclusive return variable, while in the 1980 s the return averaged only 7.1 percent. $^{5}$ Thus far in the 1990s, the average return has been 8.6 percent, but in the three most recent years, the return averages 9.6 percent.

The average rate of return over the 1994-1996 period has been higher than that in any year since 1969 . The recent increase in rates of return was not widely anticipated ${ }^{6}$, but after the fact, one can ask if recent years have, in some sense, been "unusual." One way to address this question is simply by including an indicator variable for the 1994-1996 period in a regression equation for the 1959-1996 period. $^{7}$ The coefficient estimate corresponding to this variable is positive, 0.93 with a standard error of 0.72 , so one would not reject the null hypothesis that the recent returns are drawn from the same distribution as the returns in the 1959-1993 period. Controlling for the civilian unemployment rate reduces this estimated coefficient to $0.65(0.63)$. Thus it does not seem as though there is any evidence, at this

\footnotetext{
${ }^{5}$ Feldstein, Poterba, and Dicks-Mireaux (1983) use an earlier set of NIPA data to compute rates of return for the period 1947-1979, and report that the mean pretax return for the 19501959 period was 11.7 percent. This supports the notion that the currently observed rate of return is not historically unusual.

${ }^{8}$ One indication of the surprise in recent returns can be obtained from federal corporate income tax forecasts. In 1991, the Congressional Budget Office (1991) forecast that corporate income tax revenues over the 1993-1996 period would average 1.6 percent of GDP. By 1993, this forecast had been revised upward to 1.8 percent of GDP. Actual corporate income taxes over this period have averaged 2.1 percent of GDP, largely on the strength of higher corporate earnings.
}

${ }^{7}$ This equation is estimated with an $A R(1)$ correction because the rate of return series is highly serially correlated. 
stage, that recent experience is extraordinary.

The pretax return on nonfinancial corporate capital is the relevant variable for discussions of the additional national income that would be generated by additional capital investment. From the standpoint of investors who might provide the financial capital to expand the capital stock, however, the after-tax return is of substantial interest. The difference between the pretax and after-tax returns is important as well, since it determines the deadweight burdens associated with the taxation of corporate capital income.

The third column of Table 1 presents the after-corporate-tax return on NFC assets. This series subtracts the two taxes levied at the corporate level, the corporate income tax and the property tax, from pretax profits and interest payments. This return series describes the pretax return available to investors before the payment of any investor-level taxes on capital income. It would correspond to the return available to a non-taxed investor, such as a foundation or a pension fund. This return series averages 5.1 percent, or more than three percentage points less than the pretax return, for the 1959-1996 period. For the most recent six years, the after-corporate-tax return averages 5.9 percent.

The after-corporate-tax return has been substantially higher in the last four years than in previous years because of an increase in pretax profits. When pretax returns were last at their current levels, during the late 1960s, average corporate tax burdens were substantially higher. For the 1965-1969 period, for example, the average pre-property-tax return on NFC assets was 11.2 percent, 2.6 percentage points above the 1990-1996 level, but the average after-corporate-tax return was 6.3 percent, only 0.4 percentage points above the recent level.

The data in the third column of Table 1 describe the after-tax return to an investor who does not face any taxes on capital income, but many investors do face such taxes on interest income, dividends, and capital gains. A more complete measure of the tax burden on 
corporate capital income must consider these taxes. To estimate these taxes, it is necessary to aggregate across different types of investors and to make some strong assumptions about the tax treatment of different types of capital income flows. I follow a procedure suggested in Feldstein and Summers (1979), and extended in Feldstein, Poterba, and Dicks-Mireaux (1983), by computing a "weighted average marginal tax rate" on corporate interest payments, dividend payments, and on the capital gains that are associated with corporate shares. This procedure assumes that nominal capital gains on equities arise from three sources: retained earnings, inflation-induced gains to stockholders as the real value of outstanding bonds is eroded, and nominal appreciation of corporate tangible assets. The second and third factors depend on the rate of inflation, and make the total tax burden on corporate capital income a function of the aggregate inflation rate. The appendix describes the tax rate algorithm in further detail.

The last column of Table 1 shows the after-tax return to investors after corporation income taxes, property taxes, and investor-level taxes on corporate capital income. The average after-tax return over the 1959-1996 period equals 3.9 percent. For the 1990 s, the after-tax return averages 5.0 percent, which is more than sixty basis points higher than in any previous decade. The high after-tax returns of the 1990 s reflect both an increase in pretax returns relative to the 1970 s and 1980 s, and a decline in the total tax rate on corporate earnings relative to the 1960 s.

\section{Average Tax Burdens}

Table 2 provides more detailed information on the total tax burden that falis on corporate capital income. The first column shows the corporate income tax burden on the nonfinancial corporate sector. For the 1990-1996 period, the average corporate tax burden is $\mathbf{2 1 . 5}$ percent on the average pretax return of $\mathbf{8 . 6}$ percent. This is lower than the statutory 
corporate tax rates of 34 and 35 percent that prevailed during this period because interest payments are included in the pretax return measure, but are not part of the corporate tax base, and because various tax provisions such as accelerated depreciation reduce the size of the corporate tax base relative to equity earnings in the NIPA. There has been little change in the average corporate income tax burden in the last fifteen years; this tax rate averaged 23 percent in the 1980s, and 21.5 percent in the 1990s. The corporation tax burden declined in the early 1980s as a result of the Economic Recovery Tax Act of 1981. The average rate was 33.5 percent in the 1970 s. The data do not support claims that the recent increase in after-tax profitability is due to a decline in corporate income taxation.

The second column in Table 2 reports the property tax burden on corporate tangible assets as a fraction of the pretax return. The table shows that this tax leads to a substantial reduction in the after-tax return on nonfinancial corporate assets. The average property tax burden over the 1959-1996 period is 10.3 percent, with the highest burden in the 1970s, when property taxes averaged 12.2 of pretax profits plus interest. Property taxes tend to be set in proportion to asset values, so the average property tax burden on corporate capital income rises when the rate of return on corporate assets declines.

The third column of Table 2 reports the average tax burden on the investors who hold corporate debt and equity. Although untaxed institutions such as pension funds and foundations account for substantial and growing shares of both debt and equity ownership, investor-level taxes still contribute to a substantial increase in the total tax burden on corporate capital income. ${ }^{8}$ The average tax burden at the investor level, for the 1959-1996 period, is 14.3 percent, with some fluctuation over time. The tax burden peaked in the

\footnotetext{
${ }^{8}$ In 1996 , my estimates suggest that 64 percent of corporate equity was held by taxable investors, as was 60 percent of the interest-bearing debt stock of nonfinancial corporations.
} 
1970s, when marginal tax rates on individuals reached 70 percent on unearned income, and inflation generate substantial spurious capital gains and their associated tax liabilities. The decline in marginal tax rates in the 1980s, along with falling inflation, has contributed to an investor level tax burden for the 1990-1996 period that averages 10.8 percent, less than two thirds of the rate in the 1970 s.

The final column of Table 2 reports the total tax rate that applies to corporate capital income. This rate averages 54.1 percent over the $1959-1996$ period, and it is roughly twice as great as the corporation income tax burden alone. The total tax burden shows a substantial decline between the 1970s and the 1990s, from an average of 64 percent to 42 percent. Most of the decline during the 1980 s was due to changes in the corporate income tax, while most of the decline between the 1980s and the 1990s has been the result of declining tax burdens at the investor level.

Issues of Interpretation

One difficulty with the rate of return as measured in equation (5), and the tax burden as reported in Table 2, is that these are average returns and tax rates, not the marginal returns and taxes that are likely to drive behavior. ${ }^{9}$ Average and marginal returns may diverge for well-known reasons; this makes it problematic to use average return values to evaluate the social return from additional capital accumulation. If firms earn returns on intangible assets that are not included in the measured capital stock, such as patents or trade secrets, then the average return will not equal the marginal return. There is anecdotal evidence that intangible assets, such as software, are an increasingly important share of the total "capital" stock, so the magnitude of this bias may be growing. The share of information processing equipment

\footnotetext{
${ }^{9}$ If the production function is homogeneous of degree one and capital is homogeneous, then the marginal return on corporate capital, $F_{k}$, will equal the average return, $r_{k}$ above, times the relative price of capital goods $\left(p_{k} / p\right)$.
} 
in nonresidential fixed investment was 28.2 percent in 1995, up from 19.9 percent five years earlier, and 9.9 percent in 1980. Since software and intangible assets are used in conjunction with this equipment, the importance of these intangibles may also have increased. In addition, the type of capital goods that are the subject of new investment may differ from those in the current capital stock, leading to divergence between average and marginal returns. ${ }^{10}$ Some economic shocks, such as a change in factor prices that renders existing capital relatively unproductive while raising the return to new investments. Although average returns are often used as an indication of the potential returns from additional capital investment, it is nevertheless important to remember their limitations.

A similar caveat applies with respect to tax burdens. While the tax rate calculations embody estimates of weighted average marginal tax rates where possible, for example with respect to individual interest and dividend tax burdens, at several stages they assume that marginal corporate projects will be financed in the same fashion as the existing stock of projects. While there is no academic consensus on what determines corporate dividend and debt policies, which makes it difficult to improve upon the current "average financial mix" algorithm, it is nevertheless important to flag the average rather than marginal nature of this calculation.

\section{National Income Shares}

The foregoing discussion has centered on the rate of return to corporate capital, rather than the share of corporate capital income in national income. As noted at the outset, however, the income share and the rate of return are closely related. We now present basic information on the history of profits, corporate capital income, and labor compensation relative

\footnotetext{
${ }^{10}$ The "putty-clay" nature of capital goods is a key feature of the models developed by Blanchard (1997) and Caballero and Hammour (1997) to explain recent fluctuations in the rate of return in Europe.
} 
to national income." The first column of Table 3 presents time series data on pretax corporate profits, including the capital consumption and inventory valuation adjustments, as a percentage of national income. This is the sum of profits from financial and nonfinancial firms, but seignorage earnings of the Federal Reserve Board, which are included in the NIPA aggregate for "corporate profits," are excluded from profits in tables in this paper. The data show the recent increase in the national income share of corporate profits, as well as the low level of profits in the 1980 s by comparison to other decades. The national income share of profits averaged 12.5 percent in the $1960 \mathrm{~s}, 9.9$ percent in the $1970 \mathrm{~s}, 8.0$ percent in the 1980s, and 9.1 percent for the 1990s (1990-1996). This series displays substantial change in the last half decade, with an increase from 8.2 percent in 1992 to 10.5 percent in 1996 . The lowest ratio of corporate profits to national income for this sample period was observed in 1982 (6.4 percent).

The second column of Table 3 reports the ratio of profits plus interest payments to national income, because this ratio is robust to changes in the mix of corporate payouts between debt and equity claimants, and to fluctuations in the nominal interest rate. ${ }^{12}$ The profit share of national income and the corporate capital income share move together, but the movements in the latter series are more muted. Between 1992 and 1996, for example,

\footnotetext{
"The year 1959 is the start date for a number of data series in the recently-revised national income and product accounts, so it is the beginning of the current paper's sample. While the calculations reported here divide profits and corporate capital income by national income, the patterns would be similar if these series were divided by GDP. National income ( $\$ 6164$ billion in 1996 ) equals GDP ( $\$ 7576$ billion) less capital consumption ( $\$ 846$ billion), indirect business taxes ( $\$ 618$ billion), and small adjustments for the net international flow of factor income and for the subsidies of government enterprises.

${ }^{12}$ Property taxes, which are considered an indirect tax in the NIPA, are not included in national income. They are therefore excluded from the capital income share calculations in Table 3. The results would not be substantially different if national income were expanded to include property taxes, and these taxes were added to pre-tax corporate capital income.
} 
corporate capital income as a share of national income rose 2.0 percentage points, compared with a 2.3 percentage point rise for the profit-to-national income ratio. In 1992, corporate capital income as a share of national income declined by more than the coincident decline in profits as a share of national income.

The comparison of the first and second columns shows that part of the increase in corporate profits during the last half decade reflects a shift in the allocation of corporate cash flow from interest payouts to dividends and retained earnings. In 1990, the ratio of net interest payments by domestic corporations to dividend payments by these firms equalled 113.5 percent. By 1996, this ratio had declined to 56.2 percent. The decline of interest payouts reflects falling nominal interest rates as well as a changing debt-to-capital ratio. In 1990, the BAA interest rate averaged 10.36 percent, compared with 8.29 percent in mid1996. If the interest rate on all corporate borrowing in 1990 had been $(8.29 / 10.36)$ times its actual level, then the ratio of interest to dividend payouts would have been 90.8 percent, rather than 113.5 percent. This suggests that changes in nominal interest rates can explain approximately half of the movement in this ratio over the last six years.

The ratio of corporate capital income to national income $(Y)$ can be decomposed into the product of two ratios:

$$
\text { (Profits }+ \text { Interest }) / Y=\{\text { (Profits }+ \text { Interest }) / \text { Assets }{ }^{*}(\text { Assets } / Y) \text {. }
$$

For the purposes of this calculation, tangible assets are measured at replacement cost $\left(p_{k} K\right.$ in the notation above) and they include assets held both by the financial and non-financial sectors. Tangible assets for the entire corporate sector were estimated, using data from the Balance Sheets of the U.S. Economy as a starting point, as described above.

The third and fourth columns of Table 3 show the two ratios that are multiplied on the right hand side of (7). The third column is very similar to the rates of return discussed above; 
it applies to the entire corporate sector rather than the nonfinancial corporate sector. The movements are similar, and will not be discussed further. The last column in Table 3, which reports the ratio of tangible assets to national income, is more interesting. This capital-tooutput ratio averages 1.68 over the $1959-1996$ period, with some variation. The asset-toincome ratio rises throughout the 1970s and early 1980s, and then begins to decline in the mid-1980s. It declines more rapidly in the 1990s than in the previous decade. The ratio of the replacement value of corporate assets to national income declined from an average value of 1.59 in $1990-92$, to 1.35 in 1996, a decline of just over fifteen percent. The ratio of the replacement value of the capital stock to national income is now at its lowest level in the post-1959 period.

The recent decline in the assets-to-national income ratio $\left(p_{k} K / p Y\right)$ is the result of changes in the relative price of tangible assets, $p_{k} / p$, not changes in the ratio of physical capital to output $(K / Y)$. The year-end replacement value of plant and equipment relative to national income declines by three percent (from 1.106 to 1.074) between 1990 and 1994 , and the ratio of inventories to national income falls from 0.220 to 0.200 . The decline in the tangible asset to national income ratio over this period, from 1.664 to 1.441 , is thus almost completely the result of a decline in the ratio of land values to national income. The land-tonational income ratio falls from 0.306 in 1990 to 0.138 in 1994 . This decline, in turn, is due to the fall in the estimated market value of commercial real estate relative to national income during this period. The Balance Sheets compute land values as a residual after subtracting the Commerce Department's estimate of the replacement cost of corporate residential real estate from a market value estimate for commercial real estate.

While Table 3 presents information on corporate capital income share of national income, much recent attention among researchers (for example Baker and Mishel (1995)) and 
in the popular press (for example Bernstein (1995)) has focused on movements in labor's share of national income. The foregoing discussion noted that while corporate capital income and labor income represent most of national income (85 percent in 1996), the labor share is not simply one minus the corporate capital share. Proprietors' income, rental income, and interest payments from non-corporate payers are also components of national income.

Table 4 reports three measures of labor income's share of national income. The first column tracks employee compensation as a percentage of national income for the post-1959 period. This series averages 71.5 percent over the $1959-1996$ period, and in the last ten years, it has fluctuated between 71.7 percent (1989) and 73.1 percent (1992). The 1996 value, 72.2 percent, is at the lower end of the range for the last decade, but hardly low in historic terms. The second column of Table 4 shows only wages and salaries as a percentage of national income. Employee compensation includes wages as well as the costs of employerprovided benefits. ${ }^{13}$ While recent year-to-year changes in wages and salaries track changes in total compensation very well, over a longer time period, the share of wages and salaries in national income trends downward, while employee compensation as a share of national income has remained in a narrow range since the 1960 s. These divergent patterns reflect the growing share of non-wage benefits, particularly employer-provided health insurance and retirement benefits, in employee compensation.

The last column of Table 4 combines proprietors' income with employee compensation to create an expanded measure of labor's share of national income. Part of proprietors' income is capital income, but part is labor income, so this measure is probably an overestimate of labor's share. Employee compensation as a share of national income averages

\footnotetext{
${ }^{13}$ Some employer-provided benefits, such as employer-provided health insurance, are provided voluntarily, while others, such as the employer share of Social Security and Medicare taxes, are mandated.
} 
71.5 percent over the $1959-1996$ period, while adding proprietors' income raises the average to 80.7 percent. The expanded definition of labor income shows the same general pattern of stability as the employee compensation series alone, and it also displays some decline during the 1990s.

\section{Recent Movements in Factor Shares: Is There A Story?}

The 0.9 percentage point decline in employee compensation as a share of national income over the last four years has prompted some discussion, for example Baker (1995) and Bernstein (1995), of shifting factor shares in the U.S. economy. Yet several points suggest that it is premature to consider recent changes as demanding of special note. First, the labor income share in 1992 was higher than at any time since 1983, and it was the sixth highest year in the post-1959, or the post-1947, period. Some decline from this high level would not be unexpected. Second, the labor share is a cyclical time series, and much of its variation can be explained by fluctuations in aggregate economic activity. Regressing the labor share on the civilian unemployment rate for the 1959-1992 period suggests that each one percentage point increase in the unemployment rate coincides with a 0.0067 change in the compensation share of national income. The civilian unemployment rate for 1992 averaged 7.49 percentage points, and for 1996, it averaged 5.38 percentage points. The historical relationship between the unemployment rate and the compensation share would therefore predict a decline of .0142 in the compensation share between 1992 and 1996 . This decline is larger than the observed change. Straightforward cyclical correction therefore suggests that the recent events do not reflect an unusual decline in labor's share. ${ }^{14}$

\footnotetext{
${ }^{14}$ To formally test this hypothesis I estimated an $A R(1)$ regression model in which the compensation share of national income was related to the civilian unemployment rate and a dummy variable set equal to 1 in 1996, and - 1 in 1992 (this captures the 1992-1996 change). The coefficient estimate was $-0.00129(0.00463)$, which suggests that only a one tenth of one percentage point decline in the compensation share needs to be "explained" in these two
} 
Finally, there are substantial year-to-year fluctuations in national income shares, and recent changes are not unusually large. Table 5 shows the standard deviation of the one-year and four-year changes in various time series relating to the national income shares. The standard deviation of the year-to-year change in the compensation (wage) share is $0.80(0.72)$ percentage points, and the standard deviation of the four year change is $1.6(1.5)$ percentage points. Thus the change in the last four years is well within the range of change that is suggested by historical experience. These statistical observations, in conjunction with the measurement issues raised earlier, caution against concluding that recent developments represent an important departure from past experience. ${ }^{15}$

\section{International Comparisons of Rates of Return and Factor Income Shares}

The foregoing analysis of rates of return on corporate assets in the United States suggests that returns have been higher in the 1990s than in the recent past, but that the rise in returns is not outside the range of historical experience in the United States. A different, but related, question is whether these movements are unusual in comparison with returns in other nations. While the present paper focuses on the measurement of returns, a natural follow-on project would attempt to explain what determines fluctuations in returns. Barro and Sala-i-Martin (1990) and Blanchard and Summers (1986) attempt such an explanation for the pattern of real interest rates in the 1980s. For understanding the source of return fluctuations, it can be helpful to compare the experiences of different nations. If the rates of

years, and that the difference between the two years is statistically insignificant.

${ }^{15}$ Note that there could be substantively and statistically significant changes in the rate of return to corporate capital during a period when there were no statistically significant changes in the labor income share. This is because the labor income share is approximately one minus $r_{K}{ }^{*}(K / Y)^{*}\left(p_{k} / p\right)$, so changes in $r_{K}$ could be offset by changes in the capital output ratio or the relative price of capital. The decline in $K / Y$ during the 1990 s has made the changes in factor income shares less significant than the change in $r_{k}$. 
return in most major industrial nations move together, that would suggest that common shocks could explain a substantial share of the variation in observed returns. Relatively low rates of correlation across nations, in contrast, would point toward idiosyncratic factors such as country-specific investment opportunities, that might determine these patterns.

Creating comparable measures of the rate of return to corporate capital in many nations is a difficult data problem, since there are differences in definitions and measurement algorithms, particularly for capital stocks, across countries. The OECD has attempted to systematize the accounts from OECD member countries, and publishes a time series on rates of return on capital in the business sector in each issue of the OECD Economic Outlook. The underlying data are available in the OECD Business Sector Data Bank. Blanchard (1996) analyzes these data in some detail. From this data base it is possible to construct rate of return measures, in principle analogous to those above, for the G-7 countries (France, Germany, Italy, Japan, the United Kingdom, and the United States) for the period 19651996. ${ }^{16}$ While comparing the levels of returns across countries is likely to be confounded by differences in data construction, comparing the changes in profit rates is still possible.

Table 6 shows the rate of return to capital in the business sector for each of the G-7 countries over the 1965-1996 period. In the 1990s, the rate of return has increased in all but one of the G-7 nations. Japan is the outlier, with a return decline of more than two percentage points between 1989-1990 and 1995. In the OECD data, the rate of return on U.S. business sector capital rose by 1.7 percentage points between 1991 and 1996. The change was 3.5 percentage points in the U.K., 2.1, 1.8 and 1.7 percentage points in Canada, Italy, and Germany, respectively, and 0.6 percentage points in France. Thus the recent

\footnotetext{
${ }^{16}$ The OECD data bank includes data for some countries beginning in 1961, and there are missing entries for 1995 and 1996 in some countries as well. The recent missing entries were spliced using data published in the June 1997 OECD Economic Outlook.
} 
movement in the U.S. corporate return is smaller than that in a number of other major industrial nations. ${ }^{17}$ The average return in the G-7 nations rose by 1.5 percentage points, from 13.6 percent to 15.1 percent, between the 1980 s and the 1990 s. The change in the United States over this time period was somewhat larger, 2.6 percentage points.

In keeping with the discussion in previous sections regarding the year-to-year fluctuations in measured rates of return, the last row of Table 6 reports the standard deviation of the annual change in the reported return on business assets. The standard deviations average 0.9 percentage points, suggesting that a 95 percent confidence interval for the year to year changes in these rates of return would be nearly four percentage points wide. This underscores the limited information on returns that is available from the relatively short time series being analyzed here.

The correlation structure of measured returns in the G-7 countries is explored in Table 7, which reports the set of pairwise correlations between returns in different nations. The average of the twenty-one correlations in the table is 0.31 . Four of the twenty-one correlation coefficients are negative. Thus the evidence does not support strong comovement in rates of return as a general rule, even though recent experience suggests that most rates of return have increased. These findings suggest that much of the variation in measured returns may be explained by idiosyncratic rather than common factors. It is also possible that the average returns considered here are measured with substantial noise, and that uncorrelated

\footnotetext{
${ }^{17}$ The level of the returns for the United States in Table 6 is roughly twice that in the earlier estimates, based on NIPA, for the nonfinancial corporate sector. This reflects some differences between the definition of the "business sector" in the OECD and the NIPA data, as well as a more limited definition of business assets in the OECD. More worrying than the difference in levels is the low correlation $(0.23)$ between the data series in column one of Table 1 and column one of Table 6.
} 
measurement error masks a stronger correlation between actual returns. ${ }^{18}$

The international evidence can also provide some perspective on recent movements in the labor income share of national income in the United States. Table 8 presents the labor share for the G-7 nations over the 1966-1995 period. The data show very little change in the labor share in the United States during the last decade, although the average for the 1990s (66.2 percent) is 0.5 percentage points lower than the average for the 1980 s. In contrast, the average labor share for the G-7 declined by 1.4 percentage points between the 1980 s and the 1990s, and the most recent data (1995) is substantially below the early 1990s. There are sharp differences across countries in the evolution of the labor share, with declines in the continental European countries during the last decade, and some evidence of an increase in Canada and the United Kingdom. Explaining these divergent patterns is beyond the current project. Blanchard (1997) relates changing labor shares to different labor market institutions, and different macroeconomic shocks, affecting the various OECD nations.

\section{Accounting Returns versus Financial Market Returns}

The results in this paper focus on "accounting" rates of return, rather than rates of return measured in capital markets. One question that arises in discussions of the social return to capital accumulation concerns the choice between these alternative measures of

\footnotetext{
${ }^{18}$ In a setting with much higher quality data, empirical studies that test for common movements in financial market time series, such as real interest rates, reach different conclusions about the degree of capital market integration. Barro and Sala-i-Martin (1990, p.58) report that "each country's expected real interest rate depends primarily on world factors" (although they find Japan and the U.K. to have substantial idiosyncratic components). Mishkin (1984), however, concludes (p. 1354) that "the empirical evidence ... strongly rejects the null hypothesis of the equality of real euro rates across countries." Orr, Edey, and Kennedy (1995) also find significant explanatory power for country-specific variables in their model of real long-term interest rates in the OECD.
} 
returns. ${ }^{19}$ To place the accounting returns on NFC corporate assets in context, 1 computed the average return over the 1959-1996 period to an investor who held debt and equity securities issued by nonfinancial corporations in proportion to their market values. 1 measured the equity return as the real return on large capitalization stocks, and the bond return as the real return on long-term corporate bonds, as reported in Ibbotson Associates (1997). ${ }^{20}$ The average pretax real return on this debt and equity portfolio was 6.6 percent, with a standard deviation of 14.0 percent. This should be compared with the average after-corporate-tax accounting return of 5.1 percent over this time period, with a standard deviation of 1.0 percent. Thus the NIPA "accounting return" is somewhat lower than the capital market return, but not by enough to reject the null hypothesis that the two returns are equal. ${ }^{21}$ There is much greater variation in the financial market return than in the accounting return.

A related issue about the relationship between accounting and financial market returns concerns the recent increase in corporate profits and the coincident increase in the market value of U.S. stocks. Part of the popular interest in recent changes in the labor income share of national income may be related to the high returns being earned by stock market investors in the mid-1990s. Two points about the relationship between corporate capital income and

\footnotetext{
${ }^{19}$ Summers (1990) raises this question and a number of related ones, such as the appropriate treatment of risk in the definition of the social rate of return.

${ }^{20}$ I estimated the market value of debt and equity in nonfinancial corporations by capitalizing net interest payments (using the BAA interest rate) and dividend payments (using the dividend yield on the S\&P500). The resulting market value debt-equity ratio displays substantial variation over time. In 1960, the market value of equity represented 81 percent of the total market value of the nonfinancial corporate sector. This ratio declined to 72 percent in 1970, and 67 percent in 1980, and has subsequently increased to 87 percent in 1996. Data for mid-1997 would likely show an even higher ratio.

${ }^{21}$ The standard error of the mean estimate for the financial market return is 2.3 percentage points, so the average accounting return is within a one-standard-deviation confidence interval of the financial market return.
} 
the level of the stock market bear note.

First, earnings growth has been an important factor in the recent rise in equity values. Between the fourth quarter of 1992 and the fourth quarter of 1996, the price-earnings ratio for the firms in the Standard and Poor's 500 declined from 22.8 to 19.1 , while the share price index rose 70.6 percent. Thus earnings growth, at least over this period, has been even faster than the growth in share values.

Second, there are important differences between the after-tax earnings that matter for stock market values and the NIPA measures of profits and corporate capital income that are discussed in this paper. NIPA profits correspond to the domestic earnings of U.S.-based corporations, plus the profits of U.S.-based subsidiaries of foreign multinational corporations. These earnings therefore do not correspond to the worldwide earnings of the corporations traded on U.S. equity markets. Dhawan (1997) estimates that 35 percent of the earnings of corporations in the Standard and Poor's 500 Index are generated from foreign operations. For some firms, the fraction is much higher: 85 percent of Coca-Cola's current profits are from overseas.

The difference between NIPA earnings and "stock market" earnings can be illustrated for recent years. Between the fourth quarters of 1992 and 1996, the nominal earnings of firms in the S\&P500 increased by 104 percent. Over the same time period, after-tax corporate profits in the national income accounts rose 43 percent in nominal terms. While both measures suggest that corporate profits rose, the divergence between the two series cautions against using NIPA data to investigate movements in share prices.

\section{Further Directions}

This paper has presented new evidence on the rate of return to corporate tangible assets in the United States, and on relative movements in the share of capital and labor 
income in national income. Newly-revised estimates of the replacement cost of the corporate capital stock suggest that the average pretax rate of return in the nonfinancial corporate sector, over the period 1959-1996, has been 8.5 percent. Taxes on corporations and the investors who supply capital to corporations have absorbed, on average, 54.1 percent of this return, leaving an average after-tax return to investors of 3.9 percent. The paper also considers movements in factor income shares, and finds that although rates of return on corporate assets have increased in the 1990s, a decline in the capital-to-output ratio has resulted in very little change in the national income shares accruing to capital and labor. The rise in rates of return in the United States during the current decade coincides with an increase in returns in most other industrialized nations.

The results in this study provide updated information of a type that has been used in past research to evaluate the social returns to capital formation. For those who rely on such estimates, the new data should prove useful. However, this paper has not directly addressed the set of difficult issues that arise in translating average returns such as those reported here into estimates of the social return to additional capital accumulation. These include the difference between marginal and average returns, the choice between rate of return measures based on accounting data rather than financial market data, and the possibility that rents or monopoly power make the social rate of return different from the private return. Rotemberg and Woodford (1997) discuss some of these issues in the context of a general equilibrium model with imperfect competition. All of these issues require further analysis.

This paper has also stopped short of explaining time series fluctuations in accounting rates of return, or the financial market returns that are associated with claims on corporate assets. Any such analysis requires a fully-specified model of capital market equilibrium, with appropriate attention to issues such as the degree of integration across international capital 
markets and the source of exogenous shocks to financial markets. Given the conflicting empirical evidence to date on the degree of linkage in global capital markets, and the importance of such linkage for a range of questions in applied macroeconomics, further attention to these issues is warranted. 


\section{REFERENCES}

Abel, A., Mankiw, N.G., Summers, L., and Zeckhauser, R.

(1989). Assessing Dynamic Efficiency: Theory and Evidence. Review of Economic Studies, 56: 1-20.

Baker, D.

(1996). Trends in Corporate Profitability: Getting More for Less? Economic Policy Institute, Washington, DC.

Baker, D. and Mishel, L.

(1995). Profits Up, Wages Down. Economic Policy Institute Briefing Paper, Washington DC.

Barro, R., and Sala-i-Martin, $X$.

(1990). World Real Interest Rates. In O. Blanchard and S. Fischer, eds., NBER Macroeconomics Annual: 1990. Cambridge, MIT Press.

Bernstein, A.

(1995). The Wage Squeeze. Business Week (July 17), 54-62.

Blanchard, 0 .

(1996). Notes on the Evolution of Profit Rates in the OECD. MIT Department of Economics mimeo.

(1997). The Medium Term. Brookings Papers on Economic Activity 1997:2.

Blanchard, O., and Summers, L.H.

(1984). Perspectives on High World Real Interest Rates. Brookings Papers on Economic Activity 1984:2, 273-324.

Caballero, R. J., and Hammour, M. L.

(1997). Jobless Growth: Appropriability, Factor Substitution, and Unemployment. Mimeo, MIT.

Diamond, $P$.

(1965). National Debt in a Neoclassical Growth Model, American Economic Review 55: $1126-1150$.

Dhawan, J.

(1997). An Economic Revolution: Foreign Direct Investment. Boston: Wellington Management Research.

Feldstein, M. S.

(1977). Does the United States Save Too Little? American Economic Review 67 (May): 116-121. 
(1996). The Missing Piece in Policy Analysis: Social Security Reform, American Economic Review 86 (May): 1-14.

Feldstein, M. S., Poterba, J., and Dicks-Mireaux, L.

(1983). The Effective Tax Rate and the Pretax Rate of Return, Journal of Public Economics 21: 129-158.

Feldstein, M. S., and Summers, L.

(1977). Is the Rate of Profit Falling?, Brookings Papers on Economic Activity 1: 211227.

(1979). Inflation and the Taxation of Capital Income in the Corporate Sector, National Tax Journal 32: 445-470.

Fraumeni, B. M.

(1997). The Measurement of Depreciation in the U.S. National Income and Product Accounts. Survey of Current Business 77 (July): 7-23.

Gordon, R. H.

(1997). High Personal Tax Rates and Entrepreneurial Activity: Theory and Preliminary Evidence for the United States, mimeo, University of Michigan.

Holland, D. and Myers, S.

(1979). Trends in Corporate Profitability and Capital Costs. In R. Lindsay, ed., The Nation's Capital Needs: Three Studies. Washington, DC: Committee on Economic Development.

Ibbotson Associates.

(1997). Stocks Bonds Bills and Inflation: 1997 Yearbook. Chicago: Ibbotson Associates.

Katz, A. J., and Herman, S. W.

(1997). Improved Estimates of Fixed Reproducible Tangible Wealth, 1929-1995. Survey of Current Business 77 (May): 69-92.

Mishkin, F. S.

(1984). Are Real Interest Rates Equal Across Countries? An Empirical Investigation of International Parity Conditions. Journal of Finance 39: 1345-1357.

Nordhaus, W. D.

(1974). The Falling Share of Profits. Brookings Papers on Economic Activity 1: 169208.

Orr, A., Edey, M., and Kennedy, M.

(1995). The Determinants of Real Long-Term Interest Rates: Seventeen Country Pooled Time-Series Evidence. OECD Economics Department Working Paper 
155, Paris.

Phelps, E. S.

(1961). The Golden Rule of Accumulation: A Fable for Growthmen. American Economic Review 51: 638-643.

Poterba, J. M.

(1987). Tax Policy and Corporate Saving. Brookings Papers on Economic Activity 1987:2, 455-503.

(1997). Taxation, Risk-Taking, and Household Portfolio Behavior. In A. Auerbach and M. Feldstein, eds., Handbook of Public Economics, Volume III. Amsterdam: North Holland.

Rippe, R. D., and Lavin, R. J.

(1995). Focus on ... Further Gains in Corporate Profitability, Prudential Securities Economic Outlook Monthly, August, New York, NY.

Rotemberg, J. J., and Woodford, M.

(1997). Markups, Factor Shares, and Profits Over the Business Cycle. Mimeo, MIT Sloan School of Management, January.

Slemrod, J.

(1996). Are the High-Income Surge and the Corporate Plunge Two Sides of the Same Coin? Mimeo, University of Michigan, June.

Summers, L. $\mathrm{H}$.

(1990). What is the Social Return to Capital Investment? In P. Diamond, Growth, Productivity, Employment. Cambridge: MIT Press.

U.S. Congress, Congressional Budget Office.

(1991). The Economic and Budget Outlook: Fiscal Years 1992-1996. Washington: Government Printing Office.

(1993). The Economic and Budget Outlook: Fiscal Years 1994-1998. Washington: Government Printing Office. 
Table 1: Rate of Return on Nonfinancial Corporate Capital, 1959-1996

\begin{tabular}{|c|c|c|c|c|}
\hline & $\begin{array}{l}\text { NFC Pretax Retu } \\
\text { Before Property Taxes }\end{array}$ & After Property Taxes & $\begin{array}{c}\text { NFC Return After: } \\
\text { Corporate-Level Taxes }\end{array}$ & All Taxes \\
\hline 1959 & 8.8 & 8.0 & 4.2 & 3.2 \\
\hline 1960 & 8.2 & 7.3 & 3.9 & 2.9 \\
\hline 1961 & 8.3 & 7.4 & 4.0 & 3.0 \\
\hline 1962 & 9.4 & 8.5 & 5.1 & 3.9 \\
\hline 1963 & 10.2 & 9.2 & 5.5 & 4.3 \\
\hline 1964 & 10.9 & 9.9 & 6.2 & 5.0 \\
\hline 1965 & 12.0 & 11.0 & 7.0 & 5.7 \\
\hline 1966 & 12.1 & 11.1 & 7.0 & 5.6 \\
\hline 1967 & 10.9 & 9.9 & 6.4 & 5.0 \\
\hline 1968 & 10.9 & 9.8 & 5.9 & 4.4 \\
\hline 1969 & 9.9 & 8.8 & 5.3 & 3.8 \\
\hline 1970 & 8.2 & 7.0 & 4.4 & 2.9 \\
\hline 1971 & 8.6 & 7.4 & 4.8 & 3.4 \\
\hline 1972 & 8.9 & 7.8 & 5.0 & 3.7 \\
\hline 1973 & 8.9 & 7.8 & 4.8 & 3.2 \\
\hline 1974 & 7.4 & 6.4 & 3.6 & 1.8 \\
\hline 1975 & 7.4 & 6.5 & 4.2 & 2.8 \\
\hline 1976 & 7.7 & 6.8 & 4.2 & 2.9 \\
\hline 1977 & 7.7 & 6.8 & 4.1 & 2.7 \\
\hline 1978 & 7.7 & 6.9 & 4.2 & 2.8 \\
\hline 1979 & 6.8 & 6.1 & 3.6 & 2.3 \\
\hline 1980 & 5.7 & 5.1 & 3.0 & 1.6 \\
\hline 1981 & 6.2 & 5.6 & 3.8 & 2.5 \\
\hline 1982 & 6.0 & 5.4 & 4.3 & 3.3 \\
\hline 1983 & 6.5 & 5.9 & 4.5 & 3.6 \\
\hline 1984 & 7.9 & 7.2 & 5.6 & 4.6 \\
\hline 1985 & 7.7 & 7.0 & 5.5 & 4.6 \\
\hline 1986 & 7.2 & 6.5 & 5.0 & 4.1 \\
\hline 1987 & 7.7 & 7.0 & 5.2 & 4.3 \\
\hline 1988 & 8.3 & 7.6 & 5.8 & 4.8 \\
\hline 1989 & 8.0 & 7.3 & 5.6 & 4.6 \\
\hline 1990 & 7.7 & 6.9 & 5.4 & 4.4 \\
\hline 1991 & 7.3 & 6.5 & 5.1 & 4.3 \\
\hline 1992 & 7.4 & 6.6 & 5.1 & 4.4 \\
\hline 1993 & 8.5 & 7.6 & 5.9 & 5.1 \\
\hline 1994 & 9.7 & 8.8 & 6.5 & 5.5 \\
\hline 1995 & 9.5 & 8.6 & 6.3 & 5.4 \\
\hline 1996 & 9.9 & 9.0 & 6.7 & 5.8 \\
\hline $1959-9$ & 6 Average 8.5 & 7.6 & 5.1 & 3.9 \\
\hline $1960-6$ & 9 Average 10.3 & 9.3 & 5.6 & 4.4 \\
\hline 1970-7 & 9 Average 7.9 & 6.9 & 4.3 & 2.9 \\
\hline $1980-8$ & 9 Average 7.1 & 6.5 & 4.8 & 3.8 \\
\hline $1990-9$ & 6 Average 8.6 & 7.7 & 5.9 & 5.0 \\
\hline
\end{tabular}

Notes: Column 1 equals (NFC Pre-tax Profits with IVA \& CCA + Net Interest + NFC Property Taxes)/NFC Tangible Assets at Current Cost. Column 2 omits property taxes from the numerator. Column 3 replaces before tax profits in column 2 with after-tax profits. Column 4 subtracts an estimate, described in the appendix, of taxes on corporate capital income. 
33

Table 2: Components of Tax Burden on Earnings of NFCs, 1959-1996

\begin{tabular}{|c|c|c|c|c|}
\hline & $\begin{array}{c}\text { Corporate Income } \\
\text { Taxes }\end{array}$ & $\begin{array}{l}\text { Property } \\
\text { Taxes }\end{array}$ & $\begin{array}{l}\text { Investor } \\
\text { Taxes }\end{array}$ & $\begin{array}{c}\text { Total } \\
\text { Tax Burden }\end{array}$ \\
\hline 1959 & 43.1 & 9.2 & 11.7 & 63.9 \\
\hline 1960 & 41.5 & 10.4 & 12.9 & 64.8 \\
\hline 1961 & 40.5 & 10.8 & 12.6 & 63.8 \\
\hline 1962 & 36.6 & 9.9 & 11.8 & 58.3 \\
\hline 1963 & 36.3 & 9.4 & 11.8 & 57.5 \\
\hline 1964 & 34.3 & 9.1 & 10.7 & 54.1 \\
\hline 1965 & 33.5 & 8.5 & 10.4 & 52.4 \\
\hline 1966 & 33.7 & 8.5 & 11.3 & 53.6 \\
\hline 1967 & 32.3 & 9.6 & 12.3 & 54.2 \\
\hline 1968 & 36.1 & 9.9 & 13.7 & 59.7 \\
\hline 1969 & 36.1 & 11.0 & 15.0 & 62.1 \\
\hline 1970 & 32.4 & 13.9 & 17.4 & 63.6 \\
\hline 1971 & 31.0 & 13.3 & 15.9 & 60.2 \\
\hline 1972 & 31.1 & 12.4 & 14.9 & 58.4 \\
\hline 1973 & 33.8 & 12.1 & 17.3 & 63.2 \\
\hline 1974 & 37.1 & 14.0 & 24.1 & 75.2 \\
\hline 1975 & 30.4 & 12.7 & 18.9 & 61.9 \\
\hline 1976 & 33.8 & 11.8 & 16.5 & 62.1 \\
\hline 1977 & 34.6 & 11.5 & 18.2 & 64.3 \\
\hline 1978 & 34.9 & 10.2 & 19.1 & 64.2 \\
\hline 1979 & 36.2 & 10.2 & 20.1 & 66.6 \\
\hline 1980 & 35.8 & 11.3 & 25.2 & 72.3 \\
\hline 1981 & 27.6 & 10.5 & 22.3 & 60.3 \\
\hline 1982 & 18.4 & 10.7 & 17.5 & 46.6 \\
\hline 1983 & 20.7 & 10.0 & 14.4 & 45.1 \\
\hline 1984 & 20.6 & 8.6 & 11.9 & 41.2 \\
\hline 1985 & 19.1 & 8.9 & 11.6 & 39.6 \\
\hline 1986 & 21.1 & 9.6 & 12.1 & 42.7 \\
\hline 1987 & 23.4 & 8.9 & 11.9 & 44.2 \\
\hline 1988 & 22.5 & 8.3 & 11.2 & 42.0 \\
\hline 1989 & 21.3 & 9.0 & 12.4 & 42.7 \\
\hline 1990 & 20.4 & 9.7 & 13.0 & 43.1 \\
\hline 1991 & 19.0 & 10.2 & 12.4 & 41.6 \\
\hline 1992 & 20.4 & 10.4 & 11.0 & 41.8 \\
\hline 1993 & 20.8 & 10.2 & 10.7 & 41.7 \\
\hline 1994 & 23.0 & 9.5 & 9.6 & 42.1 \\
\hline 1995 & 23.9 & 9.6 & 10.0 & 43.5 \\
\hline 1996 & 23.0 & 9.2 & 9.0 & 41.2 \\
\hline & 10.3 & 14.3 & 54.1 \\
\hline \multicolumn{2}{|c|}{$\begin{array}{l}\text { Average } 1959-9629.5 \\
\text { Average } 1960-6936.1\end{array}$} & 9.7 & 12.3 & 58.1 \\
\hline \multirow{2}{*}{\multicolumn{2}{|c|}{$\begin{array}{l}\text { Average } 1970-7933.5 \\
\text { Average } 1980-8923.0\end{array}$}} & 12.2 & 18.2 & 64.0 \\
\hline & & 9.6 & 15.1 & 47.7 \\
\hline \multicolumn{2}{|c|}{ Average $1990-9621.5$} & 9.8 & 10.8 & 42.1 \\
\hline
\end{tabular}

Source: Author's calculations described in more detail in the appendix. 
TABLE 3: Profit and Corporate Capital Income as a Share of National Income, 1959-96

\begin{tabular}{|c|c|c|c|c|}
\hline Year & $\begin{array}{l}\text { Profit } \\
\text { Share }\end{array}$ & $\begin{array}{c}\text { Corporate Capital } \\
\text { Income Share }\end{array}$ & $\begin{array}{l}\text { (Corporate Capital } \\
\text { Income)/Assets }\end{array}$ & $\begin{array}{l}\text { Corporate Assets/ } \\
\text { National Income }\end{array}$ \\
\hline 1959 & 12.6 & 12.6 & 7.0 & 1.793 \\
\hline 1960 & 11.7 & 11.7 & 6.6 & 1.788 \\
\hline 1961 & 11.6 & 11.8 & 6.6 & 1.770 \\
\hline 1962 & 12.4 & 12.6 & 7.5 & 1.686 \\
\hline 1963 & 12.9 & 13.0 & 7.9 & 1.656 \\
\hline 1964 & 13.3 & 13.5 & 8.4 & 1.598 \\
\hline 1965 & 14.0 & 14.3 & 9.3 & 1.542 \\
\hline 1966 & 13.6 & 14.1 & 9.3 & 1.508 \\
\hline 1967 & 12.5 & 13.3 & 8.6 & 1.544 \\
\hline 1968 & 12.3 & 13.1 & 8.6 & 1.526 \\
\hline 1969 & 10.9 & 11.8 & 7.7 & 1.536 \\
\hline 1970 & 8.9 & 10.2 & 6.3 & 1.613 \\
\hline 1971 & 9.8 & 11.0 & 6.8 & 1.621 \\
\hline 1972 & 10.3 & 11.4 & 7.2 & 1.594 \\
\hline 1973 & 10.2 & 11.3 & 7.3 & 1.560 \\
\hline 1974 & 8.5 & 10.1 & 6.0 & 1.683 \\
\hline 1975 & 9.4 & 11.0 & 5.9 & 1.843 \\
\hline 1976 & 10.2 & 11.3 & 6.1 & 1.853 \\
\hline 1977 & 10.9 & 12.1 & 6.6 & 1.833 \\
\hline 1978 & 10.8 & 12.3 & 6.8 & 1.790 \\
\hline 1979 & 9.8 & 11.6 & 6.4 & 1.831 \\
\hline 1980 & 7.9 & 10.4 & 5.3 & 1.960 \\
\hline 1981 & 7.7 & 10.5 & 5.3 & 1.999 \\
\hline 1982 & 6.4 & 9.4 & 4.5 & 2.107 \\
\hline 1983 & 7.9 & 10.6 & 5.2 & 2.051 \\
\hline 1984 & 8.6 & 11.5 & 6.2 & 1.858 \\
\hline 1985 & 8.5 & 11.3 & 6.3 & 1.798 \\
\hline 1986 & 7.8 & 10.8 & 6.1 & 1.765 \\
\hline 1987 & 8.3 & 11.4 & 6.8 & 1.690 \\
\hline 1988 & 8.8 & 11.8 & 7.2 & 1.637 \\
\hline 1989 & 8.2 & 11.7 & 7.1 & 1.643 \\
\hline 1990 & 8.1 & 11.3 & 6.9 & 1.643 \\
\hline 1991 & 8.2 & 11.1 & 6.8 & 1.626 \\
\hline 1992 & 8.2 & 10.5 & 7.0 & 1.502 \\
\hline 1993 & 9.1 & 11.3 & 8.0 & 1.407 \\
\hline 1994 & 9.7 & 11.8 & 8.5 & 1.383 \\
\hline 1995 & 10.0 & 12.1 & 8.8 & 1.368 \\
\hline 1996 & 10.5 & 12.5 & 9.3 & 1.346 \\
\hline \multicolumn{5}{|l|}{ Averages: } \\
\hline $1959-96$ & 10.0 & 11.7 & 7.1 & 1.683 \\
\hline $1960-69$ & 12.5 & 12.9 & 8.0 & 1.615 \\
\hline $1970-79$ & 9.9 & 11.2 & 6.5 & 1.722 \\
\hline $1980-89$ & 8.0 & 10.9 & 6.0 & 1.851 \\
\hline $1990-96$ & 9.1 & 11.5 & 7.9 & 1.468 \\
\hline
\end{tabular}

Source: Author's calculations based on data from Table 1.16 of the NIPA, and Table Z.1 of the Federal Reserve Board Balance Sheets of the U.S. Economy, updated to incorporate newiy revised estimates of the replacement cost of the residential and nonresidental capital stock. Tangible assets entry for 1995 year end is extrapolated based on 1994 value. 
Table 4: Labor Income Shares of National Income, 1959-1996

\begin{tabular}{|c|c|c|c|}
\hline & Employee Compensation & Wages \& Salaries & $\begin{array}{c}\text { Employee Compensation } 8 \\
\text { Proprietors' Income }\end{array}$ \\
\hline 1959 & 67.9 & 62.8 & 80.5 \\
\hline 1960 & 69.0 & 63.5 & 81.1 \\
\hline 1961 & 68.7 & 63.1 & 80.9 \\
\hline 1962 & 68.4 & 62.5 & 80.1 \\
\hline 1963 & 68.2 & 62.2 & 79.7 \\
\hline 1964 & 68.2 & 62.1 & 79.3 \\
\hline 1965 & 67.5 & 61.4 & 78.5 \\
\hline 1966 & 68.3 & 61.7 & 79.0 \\
\hline 1967 & 69.4 & 62.6 & 79.7 \\
\hline 1968 & 70.2 & 63.1 & 80.3 \\
\hline 1969 & 71.8 & 64.4 & 81.6 \\
\hline 1970 & 73.5 & 65.6 & 83.1 \\
\hline 1971 & 72.7 & 64.3 & 82.2 \\
\hline 1972 & 72.3 & 63.5 & 82.1 \\
\hline 1973 & 71.8 & 62.6 & 82.1 \\
\hline 1974 & 73.5 & 63.6 & 83.0 \\
\hline 1975 & 72.8 & 62.4 & 82.2 \\
\hline 1976 & 72.7 & 61.6 & 81.9 \\
\hline 1977 & 72.2 & 60.7 & 81.2 \\
\hline 1978 & 71.9 & 60.2 & 81.0 \\
\hline 1979 & 72.3 & 60.4 & 81.2 \\
\hline 1980 & 73.7 & 61.4 & 81.6 \\
\hline 1981 & 73.1 & 60.7 & 80.6 \\
\hline 1982 & 74.1 & 61.3 & 81.0 \\
\hline 1983 & 73.2 & 60.3 & 80.1 \\
\hline 1984 & 71.3 & 58.6 & 79.2 \\
\hline 1985 & 71.7 & 59.0 & 79.6 \\
\hline 1986 & 72.5 & 59.6 & 80.3 \\
\hline 1987 & 72.3 & 59.6 & 80.3 \\
\hline 1988 & 71.7 & 59.2 & 79.8 \\
\hline 1989 & 71.7 & 59.1 & 79.8 \\
\hline 1990 & 72.1 & 59.3 & 80.1 \\
\hline 1991 & 72.6 & 59.4 & 80.5 \\
\hline 1992 & 73.0 & 59.5 & 81.5 \\
\hline 1993 & 72.7 & 59.1 & 81.0 \\
\hline 1994 & 72.4 & 58.8 & 80.8 \\
\hline 1995 & 72.4 & 58.9 & 80.8 \\
\hline 1996 & 72.2 & 58.9 & 80.6 \\
\hline \multicolumn{4}{|l|}{ Averages: } \\
\hline$\overline{1959-96}$ & 71.5 & 61.2 & 80.7 \\
\hline $1960-69$ & 69.0 & 62.6 & 80.0 \\
\hline $1970-79$ & 72.6 & 62.5 & 82.0 \\
\hline $1980-89$ & 72.5 & 59.9 & 80.2 \\
\hline $1990-96$ & 72.5 & 59.1 & 80.8 \\
\hline
\end{tabular}

Source: Author's calculations based on data from Table 1.16 of the National Income and Product Accounts. 
Table 5: Standard Deviation of Year-to-Year Changes in National Income Shares, 1959-96

Standard Deviation

One Year Change

Four Year Change

\begin{tabular}{lll}
\hline Corporate Profits & 0.85 & 1.81 \\
Corporate Capital Income & 0.71 & 1.45 \\
Employee Compensation & 0.80 & 1.60 \\
Wages and Salaries & 0.72 & 1.50 \\
Employee Compensation & & \\
\& Proprietors' Income & 0.64 & 1.43 \\
Tangible Assets/National Income & 0.07 & 0.18
\end{tabular}

Source: Author's calculations based on data in Table 1.16 of NIPA and the Balance Sheets of the U.S. Economy. See notes to Tables 3 and 4 for further information. The standard deviation of four-year changes is calculated as the standard deviation of all four-year changes in the sample, thus it includes overlapping observations. 
Table 6: Comparative Rates of Return on Business Assets, G-7 Nations, 1966-1996

\begin{tabular}{|c|c|c|c|c|c|c|c|c|}
\hline & U.S. & Germany & France & Italy & Canada & U.K. & Japan & G-7 Average \\
\hline 1966 & 14.3 & 15.6 & 11.0 & 13.9 & 13.5 & 11.8 & 23.2 & 14.8 \\
\hline 1967 & 14.3 & 15.0 & 12.3 & 15.5 & 12.2 & 12.1 & 24.6 & 15.1 \\
\hline 1968 & 14.4 & 16.5 & 13.0 & 16.2 & 12.8 & 12.1 & 26.2 & 15.9 \\
\hline 1969 & 13.7 & 16.3 & 13.8 & 17.0 & 12.3 & 11.5 & 27.0 & 16.0 \\
\hline 1970 & 12.9 & 15.3 & 14.1 & 15.5 & 14.4 & 10.8 & 26.4 & 15.6 \\
\hline 1971 & 13.6 & 14.7 & 14.0 & 13.5 & 13.8 & 11.2 & 22.6 & 14.8 \\
\hline 1972 & 14.3 & 14.6 & 14.3 & 13.9 & 14.0 & 11.1 & 21.9 & 14.9 \\
\hline 1973 & 15.0 & 14.4 & 14.8 & 14.0 & 16.4 & 11.3 & 20.3 & 15.2 \\
\hline 1974 & 13.7 & 13.0 & 13.3 & 13.0 & 16.7 & 9.7 & 16.1 & 13.6 \\
\hline 1975 & 13.5 & 12.5 & 11.3 & 11.1 & 15.9 & 8.7 & 14.1 & 12.4 \\
\hline 1976 & 14.2 & 13.2 & 11.3 & 11.6 & 15.6 & 9.6 & 14.1 & 12.8 \\
\hline 1977 & 14.6 & 13.1 & 11.4 & 11.3 & 15.1 & 10.2 & 13.8 & 12.8 \\
\hline 1978 & 15.2 & 13.2 & 11.7 & 11.8 & 16.1 & 10.2 & 14.6 & 13.3 \\
\hline 1979 & 15.0 & 13.1 & 11.6 & 12.6 & 17.8 & 9.6 & 14.3 & 13.4 \\
\hline 1980 & 13.9 & 11.7 & 10.6 & 12.5 & 19.2 & 8.5 & 14.0 & 12.9 \\
\hline 1981 & 13.9 & 11.1 & 10.4 & 11.6 & 18.5 & 8.2 & 13.6 & 12.5 \\
\hline 1982 & 12.7 & 10.9 & 10.3 & 11.6 & 16.1 & 9.0 & 13.2 & 12.0 \\
\hline 1983 & 14.3 & 11.7 & 10.5 & 11.7 & 18.0 & 9.9 & 13.1 & 12.7 \\
\hline 1984 & 15.8 & 12.1 & 11.0 & 12.5 & 19.5 & 10.0 & 13.6 & 13.5 \\
\hline 1985 & 16.2 & 12.3 & 11.5 & 12.8 & 19.6 & 10.3 & 14.1 & 13.8 \\
\hline 1986 & 16.2 & 12.8 & 12.9 & 14.2 & 19.3 & 9.8 & 14.4 & 14.2 \\
\hline 1987 & 16.2 & 12.6 & 13.2 & 14.3 & 20.0 & 10.3 & 14.3 & 14.4 \\
\hline 1988 & 16.5 & 13.2 & 14.1 & 14.8 & 20.4 & 10.3 & 15.1 & 14.9 \\
\hline 1989 & 17.5 & 13.5 & 14.8 & 14.9 & 19.9 & 9.8 & 15.5 & 15.1 \\
\hline 1990 & 17.3 & 14.2 & 14.7 & 14.6 & 18.3 & 9.3 & 15.6 & 14.8 \\
\hline 1991 & 16.8 & 13.3 & 14.5 & 14.4 & 17.7 & 9.0 & 15.5 & 14.5 \\
\hline 1992 & 17.6 & 13.1 & 14.6 & 14.3 & 17.5 & 10.0 & 14.8 & 14.6 \\
\hline 1993 & 18.1 & 12.8 & 14.2 & 14.1 & 17.9 & 11.3 & 14.5 & 14.7 \\
\hline 1994 & 18.6 & 13.6 & 15.1 & 15.5 & 18.7 & 12.1 & 14.1 & 15.4 \\
\hline 1995 & 18.6 & 14.4 & 15.4 & 16.1 & 19.8 & 11.9 & 13.7 & 15.7 \\
\hline 1996 & 18.7 & 15.0 & 15.3 & 15.9 & 19.9 & 12.5 & 14.5 & 16.0 \\
\hline \multicolumn{9}{|l|}{ Averages: } \\
\hline $1966-96$ & 15.4 & 13.5 & 12.9 & 13.8 & 17.0 & 10.4 & 16.9 & 14.3 \\
\hline $1960-69$ & 14.2 & 15.8 & 12.5 & 15.6 & 12.7 & 11.9 & 25.3 & 15.4 \\
\hline $1970-79$ & 14.2 & 13.7 & 12.8 & 12.8 & 15.6 & 10.2 & 17.8 & 13.9 \\
\hline $1980-89$ & 15.3 & 12.2 & 11.9 & 13.1 & 19.0 & 9.6 & 14.1 & 13.6 \\
\hline $1990-96$ & 17.9 & 13.8 & 14.8 & 15.0 & 18.5 & 10.9 & 14.7 & 15.1 \\
\hline S.D. $(\Delta)$ & 0.7 & 0.7 & 0.7 & 0.9 & 1.1 & 0.7 & 1.3 & \\
\hline
\end{tabular}

Source: Author's calculation based on data in OECD Business Sector Data Base. The return on business assets is defined as business sector output, less wage payments, divided by the current cost estimate of the business sector capital stock. The last row, S.D. $(\Delta)$, reports the standard deviation of the annual changes in the rates of return. 
Table 7: Correlation Matrix for Rates of Return on Business Capital, G-7 Nations

\begin{tabular}{|c|c|c|c|c|c|c|}
\hline & Japan & Germany & France & Italy & U.K. & Canada \\
\hline U.S. & -0.41 & 0.03 & 0.63 & 0.44 & 0.29 & 0.65 \\
\hline Japan & 1.00 & 0.83 & 0.22 & 0.55 & 0.55 & -0.80 \\
\hline Germany & & 1.00 & 0.53 & 0.75 & 0.76 & -0.58 \\
\hline France & & & 1.00 & 0.76 & 0.50 & 0.12 \\
\hline Italy & & & & 1.00 & 0.69 & -0.09 \\
\hline U.K. & & & & & 1.00 & -0.33 \\
\hline
\end{tabular}

Source: All correlations are based on rates of return reported in Table 6 . Correlations are estimated for the period 1966-1996. Underlying data is drawn from the OECD Business Sector Data Base. 
Table 8: Labor Shares of Business Sector Output, G-7 Nations, 1966-1995

\begin{tabular}{|c|c|c|c|c|c|c|c|c|}
\hline & U.S. & Germany & France & Italy & Canada & U.K. & Japan & G-7 Average \\
\hline 1966 & 66.8 & 63.6 & 71.2 & 62.9 & 69.3 & 69.8 & 59.0 & 66.1 \\
\hline 1967 & 66.6 & 62.9 & 68.3 & 63.0 & 71.4 & 69.4 & 57.8 & 65.6 \\
\hline 1968 & 67.2 & 61.4 & 69.0 & 61.9 & 69.9 & 69.0 & 56.7 & 65.0 \\
\hline 1969 & 68.7 & 62.2 & 68.2 & 60.4 & 70.8 & 69.8 & 56.6 & 65.2 \\
\hline 1970 & 69.7 & 64.1 & 67.6 & 62.9 & 65.8 & 71.4 & 57.4 & 65.5 \\
\hline 1971 & 68.2 & 64.7 & 67.8 & 65.0 & 66.0 & 69.2 & 61.4 & 66.0 \\
\hline 1972 & 67.9 & 65.1 & 67.1 & 64.6 & 65.9 & 68.8 & 62.0 & 65.9 \\
\hline 1973 & 67.8 & 66.0 & 66.6 & 64.3 & 63.5 & 68.8 & 63.8 & 65.8 \\
\hline 1974 & 69.2 & 67.7 & 68.0 & 64.0 & 63.1 & 71.3 & 67.1 & 67.2 \\
\hline 1975 & 67.2 & 67.4 & 71.4 & 68.0 & 64.0 & 73.9 & 70.3 & 68.9 \\
\hline 1976 & 66.9 & 66.4 & 71.2 & 66.7 & 64.7 & 71.0 & 70.5 & 68.2 \\
\hline 1977 & 66.6 & 66.7 & 70.7 & 67.0 & 65.5 & 68.0 & 71.0 & 67.9 \\
\hline 1978 & 66.5 & 66.3 & 70.1 & 66.1 & 63.9 & 67.5 & 69.7 & 67.2 \\
\hline 1979 & 66.8 & 66.5 & 70.0 & 65.1 & 62.2 & 68.7 & 69.6 & 67.0 \\
\hline 1980 & 67.9 & 68.7 & 71.7 & 64.6 & 62.0 & 70.9 & 69.1 & 67.8 \\
\hline 1981 & 67.3 & 69.1 & 71.8 & 65.4 & 63.4 & 71.1 & 69.7 & 68.3 \\
\hline 1982 & 68.4 & 68.7 & 71.5 & 65.2 & 64.7 & 69.3 & 70.2 & 68.3 \\
\hline 1983 & 66.7 & 66.5 & 70.8 & 65.9 & 61.9 & 67.7 & 70.4 & 67.1 \\
\hline 1984 & 66.0 & 65.5 & 69.3 & 64.3 & 60.6 & 68.1 & 69.5 & 66.2 \\
\hline 1985 & 65.9 & 65.0 & 68.0 & 63.8 & 61.2 & 67.8 & 68.1 & 65.7 \\
\hline 1986 & 65.9 & 64.3 & 65.1 & 61.9 & 62.2 & 69.0 & 67.1 & 65.1 \\
\hline 1987 & 66.6 & 64.7 & 64.5 & 61.8 & 62.3 & 68.5 & 67.2 & 65.1 \\
\hline 1988 & 66.8 & 63.7 & 63.1 & 61.2 & 62.6 & 69.2 & 66.0 & 64.7 \\
\hline 1989 & 65.5 & 62.9 & 62.0 & 61.4 & 63.1 & 70.5 & 65.5 & 64.4 \\
\hline 1990 & 66.0 & 62.0 & 62.4 & 62.2 & 64.6 & 72.0 & 65.2 & 64.9 \\
\hline 1991 & 66.5 & 64.1 & 62.1 & 63.1 & 66.1 & 73.2 & 64.9 & 65.7 \\
\hline 1992 & 66.2 & 64.8 & 61.9 & 63.0 & 66.8 & 71.9 & 64.9 & 65.6 \\
\hline 1993 & 66.1 & 64.7 & 62.2 & 61.8 & 66.4 & 69.9 & 64.8 & 65.1 \\
\hline 1994 & 65.9 & 63.3 & 60.6 & 58.6 & 65.3 & 69.2 & 65.6 & 64.1 \\
\hline 1995 & 66.3 & 62.2 & 60.3 & 57.1 & 64.6 & 69.2 & 66.3 & 63.7 \\
\hline \multicolumn{9}{|l|}{ Averages } \\
\hline $1966-95$ & 67.0 & 75.0 & 67.1 & 63.4 & 64.8 & 69.8 & 65.6 & 66.1 \\
\hline $1960-69$ & 67.3 & 62.5 & 69.2 & 62.0 & 70.3 & 69.5 & 57.5 & 65.5 \\
\hline $1970-79$ & 67.7 & 66.1 & 69.0 & 65.4 & 64.5 & 69.9 & 66.3 & 67.0 \\
\hline $1980-89$ & 66.7 & 65.9 & 67.8 & 63.5 & 62.4 & 69.2 & 68.3 & 66.3 \\
\hline $1990-95$ & 66.2 & 63.5 & 61.6 & 61.0 & 65.6 & 70.9 & 65.3 & 64.9 \\
\hline S.D. $(\Delta)$ & 0.9 & 1.1 & 1.3 & 1.4 & 1.5 & 1.5 & 1.4 & \\
\hline
\end{tabular}

Source: Author's calculation based on data in OECD Business Sector Data Base. The labor share is defined as labor compensation divided by total output of the business sector. The last row, S.D. $(\Delta)$, reports the standard deviation of the annual changes in the rates of return. 


\section{Appendix: Calculation of Tax Burden on NFC Investors}

The procedure that $I$ use to estimate the total tax burden on investors in the nonfinancial corporate sector draws heavily on previous estimates by Feldstein and Summers (1979), Feldstein, Poterba, and Dicks-Mireaux (1983), and Poterba (1987). There are two steps to this procedure.

The first involves computation of a weighted-average marginal tax rate on the interest payments and dividends of the NFCs. To do this I exploit data on asset holdings by various investor groups, as well as the structure of NFC liabilities, in the Federal Reserve Board Flow of Funds. With respect to equity ownership, I assume that equity held by households $\left(E_{h h}\right)$, life insurance companies $\left(E_{k i}\right)$, other insurance companies $\left(E_{o j}\right)$, commercial banks $\left(E_{c b}\right)$, brokers and dealers $\left(E_{80}\right)$, and savings banks $\left(E_{s 0}\right)$ generates taxable income. (The Flow of Funds accounts are "net" of equity held within the corporate sector, so there is no intercorporate equity ownership to be considered.) I allocate equity held by mutual funds to the set of investors in mutual funds based on their proportional ownership of outstanding funds. The weighted average dividend tax rate in a given year is therefore:

$$
\begin{aligned}
& T_{\mathrm{DIV}}=\left\langle\tau_{\mathrm{DIV}, h h}{ }^{*} \mathrm{E}_{\mathrm{hh}}+T_{\mathrm{DIV}, \mathrm{li}}{ }^{*} \mathrm{E}_{\mathrm{li}}+\tau_{\mathrm{DIV}, \mathrm{oi}}{ }^{*} \mathrm{E}_{\mathrm{oi}}+\right.
\end{aligned}
$$

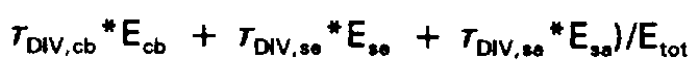

where $E_{\text {tot }}$ denotes the total stock of equity outstanding, including equity held by tax-exempt institutions. With respect to the household sector, I assume that seven percent of equity holdings are in fact held by tax-exempt institutions, and use the weighted average marginal tax rate series for dividend income in Poterba $(1987,1997)$ to define $\tau_{\text {DIV,hh }}$ in each year. The dividend tax rates for the various financial institutions recognize the intercorporate dividend exclusion rules as well as variation over time in statutory corporate marginal tax rates.

The marginal tax rate on dividends for both corporations and individuals includes state 
and local as well as federal income taxes. For individuals, state and local taxes are included by multiplying the weighted average federal marginal tax rate $\left(\tau_{\text {ov, fod,hh }}\right)$ by a factor that depends on an estimated state and local income tax rate, equal to the ratio of state and local income tax collections in the NIPA divided by national income less corporate profits. The adjustment takes the form $\tau_{\mathrm{DIV}, \mathrm{hh}}=\tau_{\mathrm{DIV}, \text { fed,hh }}{ }^{*}\left(1+\tau_{\mathrm{SL}}{ }^{*}\left(1-\tau_{\mathrm{DIV}, \text { fed,hh }}\right)\right)$ where $r_{\mathrm{SL}}$ is the estimated state and local income tax rate. For corporations, I gross up the federal statutory marginal tax rate on corporations by the ratio of federal plus state and local corporate income tax collections, divided by federal collections.

With respect to debt, the algorithm for estimating the weighted average tax burden is similar to that for equity, with two differences. First, I calculate weighted average marginal tax rates for three classes of credit market liabilities of the NFCs: corporate bonds, open market paper, and commercial mortgages. For each type of debt, I construct ownership shares as for equity above, using the relevant data from the Flow of Funds, and I compute the weighted average interest marginal tax rate on this type of debt. The three resulting marginal tax rates are then combined with weights equal to the fractions of bonds, mortgages, and commercial paper plus bank acceptances in NFC credit market liabilities. By dividing by credit market liabilities I effectively assume that all other types of debt, including trade debt, taxexempt bonds, and taxes payable, do not generate interest or associated tax burdens. This is a conservative assumption with respect to the marginal tax burden on NFC interest payouts. For consistency $\mathrm{l}$ use the weighted average marginal tax rate on household dividend receipts for the interest income tax rate as well; this allows for a single "representative investor" in the household sector.

Appendix Table A-1 shows the weighted average marginal tax rates on NFC dividend payouts, and interest income, that result from these calculation. The tax rates vary as a result 
of changes in the statutory tax rates faced by different investor classes, and as a result of changes in the distribution of stock and bond holdings across different groups with different marginal tax rates. The rise of equity ownership by pension funds during the last three decades, for example, combines with declining statutory marginal tax rates on households to reduce the marginal tax rate on dividends.

The second step in the procedure involves estimating the capital gains tax liability associated with NFC operations. Capital gains on shares can come from three sources: retained earnings that are used to purchase assets, inflationary appreciation of the nominal assets that NFCs hold, or inflation-induced revaluation of outstanding corporate liabilities, which redounds to the benefit of shareholders. To estimate the second and third components of capital gains, I assume that the capital stock appreciates at the rate of growth of the chainweighted GDP deflator, and I construct (Inflation Rate $)^{*}\left(\right.$ Tangible Assets $_{t-1}$ ) as an estimate of the nominal revaluation of assets. For the inflationary gain on corporate debt, $\mathrm{I}$ apply the same inflation rate to an estimate of the market value of NFC debt based on net interest payments capitalized at the annual average of the BAA interest rate. Table A-1 shows the three resulting components of imputed capital gains. There is substantial fluctuation in retained earnings, and in most recent years the inflation-induced revaluation of corporate assets exceeds the retained earnings as shown in the NIPA. The inflationary gains on corporate debt, as well as the inflation-induced asset revaluation term, peak during the high inflation period of the late 1970s (the entries in Table A-1 are in nominal dollars).

The total capital gain on corporate shares, equal to the sum of the three components in Table A-2, is assumed to face taxation at a weighted average marginal tax rate on capital gains, with weights corresponding to the equity ownership fractions above. For households, I make the conservative assumption that the top statutory marginal tax rate is reduced by half 
on account of capital gains deferral, and half again because some gains escape taxation through basis step-up at death. In 1996, when the top statutory marginal tax rate on capital gains was 28 percent, this results in an "effective" marginal tax rate of 7 percent. For the financial institutions in the equity ownership matrix, I follow Feldstein and Summers (1979) and assume a fifteen percent marginal tax rate on capital gains in all years.

The foregoing calculations of the average marginal tax rates that apply to each type of capital income generated by the NFCs are combined as follows. Total investor taxes in each year are then equal to:

$$
\text { TAX }_{\text {investor }}=T_{\mathrm{DIV}}{ }^{*} \mathrm{DIV}_{\mathrm{NFC}}+T_{\mathrm{INT}}{ }^{*} \mathrm{INT} T_{\mathrm{NFC}}+T_{\mathrm{CG}}{ }^{*}(\mathrm{RE}+\text { Revaluation + Debt Gain }) .
$$

The tax burden due to investor taxes is then computed as $\mathrm{TAX}_{\text {investor }} /$ (Profits + Interest + Property Taxes); this is the entry in the fourth column of Table 2. The entry in the last column of Table 1 is (Pretax Profits + Interest - Corporate Taxes - TAX investor $_{\text {) }}$ /Assets. 
Table A-1: Weighted Average Marginal Tax Rates

\begin{tabular}{|c|c|c|c|}
\hline & $\begin{array}{r}\text { Ave } \\
\text { Dividends }\end{array}$ & $\begin{array}{l}\text { ge Marginal Tax } \\
\text { Accruing Gains }\end{array}$ & $\begin{array}{l}\text { on } \\
\text { Interest }\end{array}$ \\
\hline 1959 & $36: 1$ & 5.0 & 39.2 \\
\hline 1960 & 35.1 & 4.9 & 38.4 \\
\hline 1961 & 35.7 & 4.9 & 38.1 \\
\hline 1962 & 34.9 & 4.8 & 37.9 \\
\hline 1963 & 35.1 & 4.9 & 37.8 \\
\hline 1964 & 31.8 & 4.5 & 35.9 \\
\hline 1965 & 30.5 & 4.3 & 34.1 \\
\hline 1966 & 30.8 & 4.3 & 33.8 \\
\hline 1967 & 31.2 & 4.4 & 34.1 \\
\hline 1968 & 32.2 & 4.5 & 37.1 \\
\hline 1969 & 27.7 & 5.7 & 36.0 \\
\hline 1970 & 26.7 & 5.5 & 34.0 \\
\hline 1971 & 26.3 & 5.5 & 33.8 \\
\hline 1972 & 25.6 & 5.4 & 34.2 \\
\hline 1973 & 25.3 & 5.4 & 33.9 \\
\hline 1974 & 24.8 & 5.5 & 33.9 \\
\hline 1975 & 24.1 & 5.3 & 33.6 \\
\hline 1976 & 25.2 & 5.5 & 34.5 \\
\hline 1977 & 25.9 & 5.7 & 35.2 \\
\hline 1978 & 25.0 & 5.5 & 34.6 \\
\hline 1979 & 26.2 & 4.2 & 33.7 \\
\hline 1980 & 26.9 & 4.2 & 33.3 \\
\hline 1981 & 26.6 & 4.2 & 33.5 \\
\hline 1982 & 20.8 & 3.5 & 34.1 \\
\hline 1983 & 20.2 & 3.4 & 32.9 \\
\hline 1984 & 18.3 & 3.2 & 32.9 \\
\hline 1985 & 17.7 & 3.2 & 32.8 \\
\hline 1986 & 18.1 & 3.2 & 32.5 \\
\hline 1987 & 17.0 & 4.5 & 28.3 \\
\hline 1988 & 14.7 & 4.6 & 24.6 \\
\hline 1989 & 14.9 & 4.7 & 23.9 \\
\hline 1990 & 14.3 & 4.6 & 23.6 \\
\hline 1991 & 14.9 & 4.6 & 24.0 \\
\hline 1992 & 15.2 & 4.7 & 22.8 \\
\hline 1993 & 16.2 & 4.7 & 22.8 \\
\hline 1994 & 15.9 & 4.7 & 22.0 \\
\hline 1995 & 16.0 & 4.8 & 21.6 \\
\hline 1996 & 15.9 & 4.8 & 20.9 \\
\hline
\end{tabular}

Notes: Entries describe elements that were used in calculating the investor-level tax burden on corporate capital income in the United States. See appendix for further discussion. 
Table A-2: Components of NFC Capital Gains

\begin{tabular}{|c|c|c|c|}
\hline & & Infla & Gain on: \\
\hline & Retained Earnings & Debt & Tangible Assets \\
\hline 1959 & 12.9 & 3.6 & 0.4 \\
\hline 1960 & 10.6 & 9.2 & 1.1 \\
\hline 1961 & 10.1 & 5.8 & 0.8 \\
\hline 1962 & 12.9 & 7.9 & 1.2 \\
\hline 1963 & 14.4 & 9.1 & 1.5 \\
\hline 1964 & 18.4 & 9.3 & 1.6 \\
\hline 1965 & 23.4 & 14.6 & 2.7 \\
\hline 1966 & 25.1 & 24.5 & 4.4 \\
\hline 1967 & 22.2 & 26.6 & 4.8 \\
\hline 1968 & 21.4 & 38.8 & 6.6 \\
\hline 1969 & 18.4 & 46.2 & 8.4 \\
\hline 1970 & 12.5 & 52.8 & 9.6 \\
\hline 1971 & 18.6 & 55.6 & 10.4 \\
\hline 1972 & 24.7 & 53.6 & 10.2 \\
\hline 1973 & 37.3 & 93.4 & 18.8 \\
\hline 1974 & 45.3 & 162.8 & 31.6 \\
\hline 1975 & 43.6 & 139.8 & 20.6 \\
\hline 1976 & 56.3 & 113.3 & 15.5 \\
\hline 1977 & 67.2 & 151.3 & 22.9 \\
\hline 1978 & 80.0 & 191.8 & 29.3 \\
\hline 1979 & 87.8 & 247.0 & 36.8 \\
\hline 1980 & 69.2 & 323.3 & 42.4 \\
\hline 1981 & 64.2 & 313.4 & 37.8 \\
\hline 1982 & 34.2 & 218.4 & 26.9 \\
\hline 1983 & 33.8 & 169.4 & 21.8 \\
\hline 1984 & 49.5 & 159.4 & 21.9 \\
\hline 1985 & 25.4 & 164.5 & 24.5 \\
\hline 1986 & 2.0 & 126.3 & 23.8 \\
\hline 1987 & 45.5 & 168.4 & 32.3 \\
\hline 1988 & 79.4 & 216.5 & 44.5 \\
\hline 1989 & 34.8 & 227.7 & 56.4 \\
\hline 1990 & 23.3 & 284.5 & 66.3 \\
\hline 1991 & 8.2 & 207.4 & 45.9 \\
\hline 1992 & 33.2 & 154.6 & 30.3 \\
\hline 1993 & 47.7 & 143.3 & 31.4 \\
\hline 1994 & 81.0 & 139.6 & 26.6 \\
\hline 1995 & 86.6 & 151.3 & 30.1 \\
\hline 1996 & 90.1 & 114.9 & 22.7 \\
\hline
\end{tabular}

Notes: Entries describe elements that were used in calculating the investor-level tax burden on corporate capital income in the United States. See appendix for further discussion. 